\title{
Uji Ketoksikan Akut Ekstrak Etanol Kangkung darat (Ipomoea reptans Poir) dan air (Ipomoea aquatic Forsk) Menggunakan Metode OECD 423
}

\section{Acute Toxicity test Ipomoea reptans Poir and Ipomoea aquatic Forsk of Ethanol Extract Used OECD 423 Method}

\author{
A.Ariani Hesti Wulan $\mathbf{S}^{1}$, Navtalina Putri Sekar Langit ${ }^{1}$ \\ Email: ost25hesti@gmail.com \\ ${ }^{1}$ Laboratorium Farmakologi, D3 Farmasi, STIFAR Yayasan Pharmasi Semarang \\ Riwayat Artikel: Diterima September 2021; Diterbitkan Oktober 2021
}

\begin{abstract}
Abstrak
Kangkung memiliki dua jenis yaitu darat (Ipomoea reptans Poir) dan air (Ipomoea aquatic Forsk). Kangkung dapat digunakan untuk terapi herbal antara lain sedative, hipnotik, antidiabetes, analgetik dan ansiolitik. Obat herbal pemakaiannya cukup lama yaitu lebih dari satu minggu, maka perlu diketahui keamanannya agar tidak menimbulkan efek berbahaya yang tidak diinginkan. Tujuan dari penelitian ini adalah untuk mengetahui efek toksisitas dan menentukan nilai LD $_{50}$ ekstrak etanol kangkung darat dan air menggunakan metode OECD 423. Penelitian ini menggunakan hewan uji mencit Mus musculus menggunakan dosis $300 \mathrm{mg} / \mathrm{KgBB}$, kemudian dilanjutkan dosis $2000 \mathrm{mg} / \mathrm{KgBB}$. Pemberian melalui peroral satu kali selama perlakuan, dilihat gejala fisik berupa sianosis, kejang, laju pernafasan selama 4 jam pertama dan dihitung jumlah kematian. Pengamatan dilanjutkan sampai hari ke 14 . Jika terjadi kematian pada 24 jam pertama maka dilakukan pengulangan. Hasil skrining fitokimia ektrak etanol kangkung darat dan air positif terhadap flavonoid, tannin, saponin, steroid, dan vitamin C dan E. Berdasar hasil pengamatan jumlah kematian kemudian disesuaikan dengan GHCS ekstrak etanol kangkung darat dan air memiliki $\mathrm{LD}_{50}>$ 2000-5000 mg/KgBB
\end{abstract}

Kata Kunci : kangkung, darat, air, OECD 423, ekstrak etanol,

\begin{abstract}
Kangkung have two types, namely Ipomoea reptans Poir and Ipomoea aquatic Forsk. Spinach can be used for herbal terapy including sedative, hypnotic, antidiabetic, analgetic and anxiolytic. Herbal medicine are used for a long time, which is more than a week, so it is necessary to know their safety so that they do not cause unwanted harmful effects. The purpose of this study was to determine the effect of toxicity and to determine the $L D_{50}$ value of ethanolic extract Ipomoea reptans Poir and Ipomoea aquatic Forsk using the OECD 423 method. This study used mice as test animals, Mus musculus, using a dose of $300 \mathrm{mg} / \mathrm{KgBW}$, followed by a dose of $2000 \mathrm{mg} / \mathrm{KgBW}$. Given orally once during the treatment, physical symptoms such as cyanosis, seizures, respiratory rate for the first 4 hour and the number of deaths were calculated. Observations were continued until day 14. If death occurred in the first 24 hours, it was repeated. The results of py phytochemical screening of ethanol extract Ipomoea reptans Poir and Ipomoea aquatic Forsk were positif for flavonoids, tannins, steroidal, saponins, and vitamins $C$ and $E$. Based on the results of observations, the number of deaths was then adjusted to GHCS ethanol extract Ipomoea reptans Poir and Ipomoea aquatic Forsk $L D_{50}>2000-5000 \mathrm{mg} / \mathrm{KgBW}$
\end{abstract}

Keywords : Ipomoea reptans Poir, Ipomoea aquatic Forsk, OECD 423, Ethanol extract 


\section{Pendahuluan}

Uji toksisitas akut adalah salah satu uji praklinik. Uji ini dirancang untuk mengukur derajat efek toksik suatu senyawa yang terjadi dalam waktu singkat, yaitu 24 jam setelah pemberiannya dalam dosis tunggal. Tolak ukur kuantitatif yang paling sering digunakan untuk menyatakan kisaran dosis letal atau toksik adalah dosis letal tengah $\left(\mathrm{LD}_{50}\right)$. Dalam penentuan dosis letal tengah (LD 50$)$ menggunakan metode ketoksikan akut OECD 423. Keunggulan metode ini yaitu menggunakan hewan uji lebih sedikit sehingga lebih manusiawi karena dapat meminimalkan penggunaan hewan uji dan juga lebih ekonomis dalam segi ekonomi, serta waktu perlakuan relative cepat (OECD, 2001).

Kangkung merupakan salah satu jenis sayuran yang banyak dijumpai di Indonesia, kangkung sendiri banyak dimanfaatkan sebagai salah satu sumber pangan yang sering dikonsumsi oleh masyarakat. Di Tanah Air, kangkung ini terdiri atas dua jenis, yakni kangkung air (Ipomoea aquatica Forsk) dan kangkung darat (Ipomoea reptans Poir) dengan kedua tanaman ini sama-sama merupakan tanaman herba (Lestari, 2019). Kangkung air (Ipomoea aquatica Forsk) merupakan tanaman yang lebih banyak dikenal oleh masyarakat dibandingkan kangkung darat. Kangkung mengandung protein, mineral (kalsium, fosfor, besi), vitamin (A, B1, C, karoten), hentriakontan, dan sitisterol. Menurut Yuliana (2013), kangkung mengandung senyawa kimia polifenol, flavonoid dan kuinon. Komponen bioaktif pada kangkung air, meliputi golongan alkaloid, steroid, fenol hidrokuinon dan karbohidrat. Kangkung air yang digunakan sebagai obat adalah daun, batang dan akar yang digunakan dalambentuk segar. Daun dan batang kangkung digunakan untuk mengatasi keracunan makanan (termasuk jamur dan cendawan liar), urin sedikit, kencing nanah, pendarahan, sulit tidur, sulit buang air besar, terkilir, digigit ular dan serangga. Sedangkan akar kangkung digunakan untuk mengatasi keputihan, batuk lama, radang gusi dan keringat dingin (Fajrina dkk. 2017).

Penelitian lebih lanjut telah dilakukan isolasi senyawa 7-O- $\beta-D-$ gluko piranosil dihidrokuersetin - 3-O- $\alpha$-D-glukopiranosid yang bertanggung jawab terhadap efek antioksidan pada kangkung (Wirasutisna dkk. 2012). Penelitian yang lain juga menunjukan ekstrak daun tanaman kangkung memberikan hasil pada uji aktivitas antidiabetes pada dosis 1,5 g/kgBB; $3 \mathrm{~g} / \mathrm{kgBB}$; dan 4,5 g/kgBB (Santoso, 2011). Adapula penelitian yang menunjukkan ekstrak etanol daun kangkung air memberikan efek pada uji efek sedatif yaitu pada dosis $4 \mathrm{mg} / 20 \mathrm{grBB}$ (Syamsi, 2019). Adapula penelitian yang menunjukkan ekstrak kangkung air memberikan hasil positif efek ansiolitik yaitu dosis 400mg (Rahangga dkk. 2018). Ekstrak etanol kangkung darat memberikan efek sedative pada dosis $16 \mathrm{mg} / \mathrm{KgBB}$ (Kundarto W, Pratiwi A, 2018). Oleh sebab itu perlu dilakukan pengujian lebih lanjut pada hewan uji untuk melihat ada tidaknya efek toksik untuk menjamin keamanan penggunaannya.

Hasil dari penelitian yang dilakukan diharapkan dapat memberikan informasi terkait efek toksisitas dan nilai LD $_{50}$ dan penggunaan dosis yang tepat saat membuat sediaan yang berasal dari ekstrak etanol kangkung darat dan air serta dapat mengenali tanda-tanda toksik yang terjadi.

\section{Metode Penelitian}

\section{Alat}

Alat gelas: labu takar, beaker (Pyrek), timbangan digital, sonde mencit, box kaca mencit, tabung reaksi.

\section{Bahan}

Kangkung air (Sayung, Demak), kangkung darat (Bandungan, Kab. Semarang), etanol 96\% tk (MKR), mencit putih, jantan galur Swiss, umur 3-4 minggu, BB 20-30gram, $\mathrm{HCl}, \mathrm{FeCl}_{3}$, serbuk $\mathrm{Mg}, \mathrm{Rg}$ Dragendrof

\section{Tahapan Penelitian}

1. Pembuatan simplisia

Bagian kangkung yang dipakai adalah daun dan batang. Dicuci bersih, ditiriskan dan dipotong kecil-kecil, kemudian dikeringanginkan dengan ditutup kain hitam. Setelah kering kemudian simplisia diblender, diayak dengan mesh 40/60.

2. Pembuatan Ekstrak Etanol

Ekstrak etanol dibuat dengan cara remaserasi menggunakan pelarut etanol 96\% selama 3 hari menggunakan penggantian pelarut tiap hari dengan volume yang sama $(1: 10)$. Sari yang terkumpul kemudian diuapkan menggunkan vakum evaporator pada suhu $70 \square \mathrm{C}$ sampai didapat ekstrak kental. 
3. Skrining fitokimia

a. Flavanoid

Ekstrak ditambah aquades didihkan ditambah serbuk $\mathrm{Mg}$ ditambah $\mathrm{HCl}(\mathrm{p})$ dana mil alcohol kocok, amati perubahan pada lapisan amyl

b. Alkaloid

Ektrak ditambah aquadest ditambah $\mathrm{HCl}$ 2N ditambah $\mathrm{Rg}$ Dragendrof, amati perubahan yang terjadi

c. Tanin

Ekstrak ditambah aquadest ditambah $\mathrm{FeCl} 3$ 1\%, kocok amati perubahan warna

d. Saponin

Ektrak ditambah aquadest ditambah $\mathrm{HCl}(\mathrm{p})$ dikocok diamkan 10 detik tambah $\mathrm{HCl}$, amati jumlah busa yang timbul

4. Pengujian uji ketoksikan akut

Hewan uji dikelompokkan, tiap kelompok berisi 3 hewan uji, pada dosis I $300 \mathrm{mg} / \mathrm{KgBB}$ diberikan memalui peroral, setelah 1 jam perlakuan apabila tidak ada yang mati dilanjutkan pada dosis II 2000 $\mathrm{mg} / \mathrm{KgBB}$, semua hewan uji diamati selama 24 jam terhadap gejala ketoksikan dan dihitung jumlah kematiannya, kemudian jika pada hari kedua dilakukan replikasi terhadap dosis I dan II. Semua hewan uji diamati sampai pada hari ke 14 dengan tetap diberi makan dan minum secukupnya. Hewan uji dibuat terpisah antara kelompok dosis dan antar kelompok batch. Pada hari 1 masingmasing kelompok pengujian dilihat perilakunya terhadapa perubahan fisik yaitu sianosis, kejang, dan laju pernafasan.

\section{Analisis Data}

Data jumlah hewan uji yang mati dibuat table kemudian dimasukkan dalam kriteria ketoksikan GHCS. Gejala ketoksikan yang ditimbul disampaikan dalam table dan dideskripsikan.

\section{Hasil dan Pembahasan}

Penelitian ini didahului dengan melakukan determinasi kangkung darat dan air di Laboratorium Biologi STIFAR dan telah mendapat persetujuan Etical Clearens dari KEPK Stifar untuk penelitian in vivonya. Perbedaan kangkung darat dan kangkung air terletak pada bunganya, yaitu bunga kangkung darat berwarna putih dan kangkung air putih sedikit keunguan ditengah mahkota bunga. Berdasarkan Heminawati (2011) kandungan zat aktif pada kangkung air adalah karoten, riboflavin, vitamin $\mathrm{C}$, vitamin $\mathrm{E}$. sedangkan kangkung darat menganding flavonoid, polyphenol, vitamin E.

Rendemen hasil ekstraksi etanol kangkung darat adalah 15,30\%, sedangkan kangkung air adalah 14,40\%. Pembuatan remaserasi dipilih karena rendemen dengan metode ini akan lebih banyak daripada menggunakan maserasi (tanpa penambahan pelarut). Hal ini disebabkan karena pada proses remaserasi terjadi pergantian pelarut, sehingga larutan penyari tidak jenuh.

Setelah mendapatkan ekstrak kental, kedua ekstrak diuji bebas etanol, untuk memastikan bahwa semua pelarut (etanol) sudah menguap. Hal ini dilakukan untuk memastikan bahwa zat yang akan diuji benarbenar berasal dari zat aktif ekstrak, bukan dari larutan penyari.

Uji toksisitas akut dilakukan menggunakan metode OECD 423. Pemilihan metode ini dikarenakan metode ini adalah metode yang menjadi rujukan uji toksisitas akur dari BPOM, selain itu uji ini menggunakan jumlah hewan uji yang sedikit, lama pengerjaan juga membutuhkan waktu yang sebentar.

Hasil skrining fitokimia didapat data seperti dalam tabel 1 .

Tabel 1. Hasil skrining fitokimia

\begin{tabular}{lcc}
\hline Pengujian & K. darat & K. air \\
\hline Flavanoid & + & + \\
\hline Alkaloid & + & + \\
\hline Saponin & + & + \\
\hline Tanin & + & + \\
\hline Karotenoid & + & + \\
\hline Vitamin C & + & + \\
\hline Vitamin E & + & + \\
\hline
\end{tabular}

Pengujian awal dilakukan pada dosis $300 \mathrm{mg} / \mathrm{KgBB}$ mencit. Pertimbangan dosis ini berdasar hasil penelitian terdahulu untuk efek analgetik,. Hasil uji toksisitas dapat dilihat di tabel 2 . 
Tabel 2. Jumlah kematian kewan uji

\begin{tabular}{llll}
\hline Dosis & & K. darat & K. air \\
\hline $300 \mathrm{mg} / \mathrm{KgBB}$ & 1 & 1 & 0 \\
\hline & 2 & 1 & 1 \\
\hline $2000 \mathrm{mg} / \mathrm{KgBB}$ & 1 & 0 & 0 \\
\hline & 2 & 1 & 1 \\
\hline
\end{tabular}

Kematian hewan uji ditemukan pada dosis $300 \mathrm{mg} / \mathrm{KgBB}$ kemudian dilanjutkan ke dosis 2000mg/KgBB. Kedua sediaan ditemukan jumlah hewan mati pada hari 1 pada 1 jam setelah pemberian, maka dosis tidak diteruskan ke dosis $5000 \mathrm{mg} / \mathrm{KgBB}$. Berdasar tabel 2 jumlah kematian diatas kemudian dikonversikan ke tabel GHCS maka ekstrak etanol kangkung darat dan kangkung air masuk katagori $\mathrm{V}$.

Pada pengamatan respon fisik tidak ditemukan tanda sianosis, kejang atau gagal pernafasan sampai pada 4 jam pertama, kecuali pada hewan uji yang mati ditemukan gejala sianosis mulai menit ke 45 , dilanjutkan kejang dan mati pada menit ke 70 .

Tanaman pangan, yaitu sayuran dan buah-buahan memiliki kandungan nutrien, vitamin, dan mineral yang berguna bagi pertumbuhan dan kesehatan. Meskipun demikian beberapa jenis sayuran dan buahbuahan dapat mengandung racun alami yang berpotensi membahayakan kesehatan manusia.

Racun alami adalah zat yang secara alami terdapat pada tumbuhan, dan merupakan salah satu mekanisme dari tumbuhan tersebut untuk melawan serangan jamur, serangga,serta predator. Kadar racun pada tanaman dapat sangat bervariasi. Hal itu dipengaruhi antara lain oleh keadaan lingkungan tempat tanaman itu tumbuh. Pengolahan bahan pangan juga berpengaruh terhadap kandungan racun alami padatanaman (Ramdani dkk. 2017). Didalam kangkung air terdapat kandungan enzim peroksidase yang bersifat mengkatalis reaksi oksidasi. Enzim peroksidase paling tahan terhadap panas dan akan tinggi aktivitasnya apabila dalam bahan pangan tersebut banyak terdapat zat besi. Kandungan lemak yang cukup tinggi pada daun juga akan mempercepat aktivitas enzim tersebut (Nugroho dkk. 2020)

Beberapa metabolit sekunder bersifat toksik karena merupakan bagian dari mekanisme pertahanan diri. Tanin diketahui dapat menimbulkan efek toksik berupa nekrosis hati dan pendarahan pada sistem pencernaan. Semakin tinggi dosis ekstrak yang diberikan mengindikasikan semakin besar pula kerusakan hati. Flavonoiddiketahui bersifat toksik karena dapat bekerja sebagai racun pernafasan bahkan senyawa flavonoid dapat menyebabkan keracunan perut yang menghambat daya makan sehingga mengalami kekurangan nutrisi. Saponin juga dapat senyawa toksik yang menyebabkan penurunan aktivitas enzim pencernaan dan penyerapan makanan sehingga dapat menghambat perkembangan, mengganggu pertumbuhan serta menghambat reproduksi (Siswadi, 2018). Vitamin C, vitamin E dan karetoid sebagai precursor vitamin A merupakan salah satu antioksidan, sehingga dapat membantu efektifitas kangkung.

Berdasar penelitian Tiro (2017) faktor lain yang dapat mempengaruhi kematian hewan uji adalah kandungan senyawa logam berat dalam tanaman kangkung, terutama pada kangkung air. Dalam kangkung air ditemukan bahwa kangkung air dapat mengabsorpsi logam $\mathrm{Pb}$ sebesar $0.342-0.678 \mathrm{ppm}$ sedangkan logam $\mathrm{Cu}$ sebesar $0.804-1.051$ ppm. Tanaman kangkung air mampu beradaptasi untuk bertahan hidup dalam lingkungan yang terpapar logam berat dan memiliki daya serap untuk menyerarap logam $\mathrm{Pb}$ dan $\mathrm{Cu}$.

\section{Simpulan}

Ekstrak etanol kangkung darat dan kangkung air memiliki efek toksik dalam katagori V GHCS (Globally Hormonized Classification System) yaitu praktis tidak toksik dengan nilai $\mathrm{LD}_{50}$ ektrak etanol kangkung darat dan kangkung air > 2000-5000 mg/KgBB.

\section{Ucapan Terima Kasih}

Terima kasih kepada seluruh sivitas akademika STIFAR Yayasan Pharmasi Semarang, dan untuk mahasiswa dalam tim kangkung 2020.

\section{Daftar Pustaka}

Helminawati. 2011. Uji Efek antihiperglikemia Infusa Kangkung darat (Ipomoea Reptans Poir) pada Mencit Swiss Jantan yang diinduksi Streptozotocin. Khazanah. IV (1):25-32

Fajrina, A., Jubahar, J., Hardiana, N. 2017. Uji Aktivitas Fraksi Dari Ekstrak Akar Kangkung (Ipomoea aquatica Forsk.) 
Terhadap Bakteri Streptococus mutans. Jurnal Farmasi Higea.9(2):140-148.

Nugroho, S., A., Taufika, R., Novenda, I., L. 2020. Analisis Kandungan Asam AskorbatPada Tanaman Kangkung (Ipomoea reptana Poir), Bayam (Amaranthus spinosus) dan Ketimun (Cucunis sativus L). Jurnal Tambora.4(1):26-31.

Rahangga, D. G. O., Hair, L., Sasmita, W. O. I., Sahidin. 2018. Efek Ansiolitik Ekstrak Etanol Kangkung Air (Ipomoea aquatica) Dalam Mengurangi Perasaan Cemas. Pharmauho.4(1) : 3438.

Ramdani, U., M., Oktaviani, D., Hasanah, H., N. 2017. Identifikasi Kadar Sianida Pada Biji Melinjo (Gnetum gnemon l). Jurnal Kesehatan Bakti Tunas Husada.7(2):541-545.

Kundarto, W. Pratiwi, A. 2018 Potensi Ekstrak Daun Kangkung Darat (Ipomoea reptans Poir Sebagai AGen sedative Herbal. Journal of Pharmaceutical Science and Clinical Research. 3 (1) : 12-17.

Siswadi, \& S.Saragih, G. 2018. Uji Toksisitas Akut Ekstrak Etanol Kulit Batang Faloak (Sterculia quadrifida R.Br) pada Tikus Sprague-Dawley. Traditional Medicine Journal. 23(2):127-134.

Syamsi, N., Tanra, A. A. M., Lestari, N. H. 2019. Uji Efek Sedasi Ekstrak Kangkung Air (Ipomoea Aquatica) Pada Mencit (Mus musculus). Jurnal Kesebatan Tadulako.5(2):1-71.

The Organization of Economic Co-operation and Development (OECD). 2001. The OECD Guideline for Testing of
Chemical :423 Acute Oral Toxicity. France.

Tiro, L. L., Isa, I., Iyabu, H. 2017. Potensi Kangkung Air (Ipomoea Aquatica) Sebagai Bioabsorbsi Logam $\mathrm{Pb}$ dan Cu. Jurnal Entropi.12(1):81-86.

Wirasutisna, K. R., Nawawi, A., Sari, N. 2012. Telaah Fitokimia Daun Kangkung Air (Ipomoea aquatica Forsk). Acta Pharmaceutica Indonesia.37(2):39-42.

Yuliana, A., Albert. 2013. Aktivitas kangkung air (Ipomoea aquatica) terhadap jamur Pityrosporum ovale hasil isolasi secara in vitro. Jurnal kesehatan bakti tunas busada, 9(1):1-6.

Syamsi, N., Tanra, A. A. M., Lestari, N. H. 2019. Uji Efek Sedasi Ekstrak Kangkung Air (Ipomoea Aquatica) Pada Mencit (Mus musculus). Jurnal Kesehatan Tadulako.5(2):1-71.

The Organization of Economic Co-operation and Development (OECD). 2001. The OECD Guideline for Testing of Chemical :423 Acute Oral Toxicity. France.

Tiro, L. L., Isa, I., Iyabu, H. 2017. Potensi Kangkung Air (Ipomoea Aquatica) Sebagai Bioabsorbsi Logam $\mathrm{Pb}$ dan Cu. Jurnal Entropi.12(1):81-86.

Wirasutisna, K. R., Nawawi, A., Sari, N. 2012. Telaah Fitokimia Daun Kangkung Air (Ipomoea aquatica Forsk). Acta Pharmaceutica Indonesia.37(2):39-42.

Yuliana, A., \& Albert. 2013. Aktivitas kangkung air (Ipomoea aquatica) terhadap jamur Pityrosporum ovale hasil isolasi secara in vitro. Jurnal kesehatan bakti tunas husada, 9(1):1-6 